\title{
Production of thermostone in Koya city
}

\author{
Fakhri H. Ibraheem, Roza Muhsin Fathi Shaweas \\ \& Safa Mustafa Shakir Mahmood \\ Department of Chemical Engineering, Faculty of Engineering, Koya \\ University, Kurdistan Region, Iraq
}

\begin{abstract}
The rate of construction in the Kurdistan region (KRG) has increased through the recent decade due to a wide scope of investments in different projects and especially for residential projects, infrastructure and others. Thermostone block has a good marketing demand in KRG due to its preferable specification low unit weight and exceptional thermal insulation; it is known as light weight concrete. It is used for the inner sections and in conjunction with the various insulation materials. The manufacturing technology of thermostone is not complicated, but there are limited thermostone factories in the Kurdistan region, and mainly all the thermostone construction materials are imported from outside Iraq. So the manufacturing of thermostone locally would have a positive additional value as a result of substituting imported material, providing jobs and the availability of raw materials around Koya city. The idea of this paper is to promote local and foreign investors for the establishment of thermostone factories in Koya city to produce standard blocks and panels. It is found from the study that a 10 ton/day factory capacity is a good startup to produce thermostone. It has a positive economic effect; with a total investment cost: 4404, production cost: 1356, total revenue: 1699, annual profit: 343 and investment payback period: two years and five months.

Keywords: thermostone, lightweight concrete, lime, Koya.
\end{abstract}

\section{Introduction}

It is a modern construction material that has a white medium textured surface. It is a unique and excellent type of building material due to its super heat, fire and sound resistance; it is known as light weight concrete (LWC). It was invented in the mid-1920s by the Swedish architect and inventor Johan Axel 
Eriksson [1, p. 20]. Thermostone blocks offer ultimate workability, flexibility, durability, easy to handle, quickly to install and can be easily cut, chased and fixed into. The local market demand for that material is very high in KRG for its positive specifications and because of highly building rate but there is shortage in the local production of that material due to the lack of factories it is shown that the announced information for investment in KRG shows only one factory in Erbil [2], and the main amount of thermostone that is used now in KRG is imported from other countries (Turkey or Iran) [3]. For these reasons and because of its positive economic data, the production of thermostone is considered to be an important subject for urban development. Its main ingredients include sand, water, lime, cement, and a small amount of alumina fine powder. The raw materials goes through chemical reactions under specified conditions of temperature, pressure and humidity (curing) to provide a distinct porous structure, lightness, and insulation properties. In comparison a house whose walls are built from thermostone blocks would consume $25 \%$ to $30 \%$ less electrical energy than one whose walls are built from hollow concrete blocks [4]. LWC is considered to be Green Industry due to its environmentally friendly building material that is used to save energy and enhance the quality of the built environment. LWC contains no Volatile Organic Compounds (VOCs), and can further be coated by a variety of low VOC materials. These attributes directly address the Indoor Environmental Quality Low Emitting Materials credit [5].

\section{Raw materials}

The common raw materials used to manufacture thermostone blocks in Iraq are Portland cement, hydrated lime (calcium oxide), aluminum fine powder, water, and sand.

Table 1: $\quad$ Raw materials specifications and proportions [4].

\begin{tabular}{|c|c|c|c|}
\hline No. & Material & Specifications & Wt.\% \\
\hline 1 & Sand & $\begin{array}{l}\text { Silica content more than } 80 \% \text {. } \\
\text { Sieve analysis } 85 \% \text { pass through sieve } 90 \\
\text { micron. } \\
\text { The density of the sand slurry should be not } \\
\text { more than } 1.7 \text { gm/cc. }\end{array}$ & 25 \\
\hline 2 & Lime $(\mathrm{CaO})$ & $\begin{array}{l}\text { Sieve analysis } 95 \% \text { pass through sieve } 90 \\
\text { micron. Produced by calcination of limestone } \\
\text { rock }\left(\mathrm{CaCO}_{3}\right) \text {. }\end{array}$ & $9-10$ \\
\hline 3 & $\begin{array}{c}\text { Portland } \\
\text { cement }\end{array}$ & Loss on ignition: $0.7 \%, \mathrm{CaO} \%: 70 \%$ & 25 \\
\hline 4 & $\begin{array}{c}\text { Aluminium } \\
\text { Powder }\end{array}$ & 50-100 microns & 0.04 \\
\hline 5 & Water & Tap water & 40 \\
\hline
\end{tabular}


Chemical analysis of the Koay Heibat Sultan soil shows it contains a mixture of metal oxide related to iron, alumina, magnesium, silica and calcium. The mixture of metal oxide inter inside the grain structure of thermostone and change specifications towards better strength and heat insulation. The big Portland cement factories in Sulaymaniea (Taslouga and Bazyan) are not far from Koya and according to that Koya is suitable place to establish such a factory because the raw materials are available either in Koya or around.

\section{Theory}

Aluminum powder reacts with calcium hydroxide and water to produce hydrogen gas which aerates the mixture producing millions of microscopic hydrogen bubbles.

$$
2 \mathrm{Al}+3 \mathrm{Ca}(\mathrm{OH})_{2}+6 \mathrm{H}_{2} \mathrm{O}-->3 \mathrm{CaO} \cdot \mathrm{AI}_{2} \mathrm{O}_{3} \cdot 6 \mathrm{H}_{2} \mathrm{O}+3 \mathrm{H}_{2}
$$

Aluminum powder+ hydrated lime becomes tricalcium hydrate+ hydrogen (Dunn [3]). The hydrogen bubbles cause the concrete to expand to roughly two times its original volume. The hydrogen subsequently evaporates, leaving a highly closed-cell aerated concrete. The now aerated concrete is cut into blocks or panels which are steam and pressure-cured in an autoclave [6] to build grain crystal structure of thermostone.

The chemical reaction that takes place in the presence of steam in the autoclave is:

$$
\mathrm{Ca}(\mathrm{OH})_{2}+\mathrm{SiO}_{2}+\mathrm{xH}_{2} \mathrm{O}--------\rightarrow \mathrm{CaO}^{-\mathrm{SiO}_{2}} \mathrm{xH}_{2} \mathrm{O}
$$

Lime in binder + silica + water becomes mono calcium silicate hydrate [3].

\section{Manufacturing procedures}

1. Prepare a suitable stock of raw materials that are pass the laboratory test in a silos normally three silos for cement, lime and washed grinded sand also supplied by water storage tank and containers for clay and additives (fly ash) for different block specifications. The capacity of silos, water tank and containers depend on production capacity and quality.

2. Mixing raw materials (lime, cement, sand, aluminum fine powder and water) in a pan mixer for a specified time suitable with raw material specifications and proportions and at a temperature between $43-55^{\circ} \mathrm{C}$, it was observed that no reactions occurs at a temperature less than $40^{\circ} \mathrm{C}$ [5]. The mixing process will be kept under designed constant temperature by adding cold or hot water automatically according to the requirement. The return slurry density is to be controlled every hour and to be maintained $1.4 \mathrm{gm} / \mathrm{cc}$ [7]. The mixing process is PLC controlled fully automatic system.

3. Block production: the slurry is fed into vibro-hydraulic press machine for molding into casting block and leave to settle in greased molds. It takes from 
30 minutes to 4 hours for the mixture to harden enough to be cut by wires into the desired standard dimension shapes and transported to an autoclave.

4. The blocks put on standard dimensions wooden pallet and arranged in such a way that the pressurized steam surround each block for curing which done at a pressure 10 atmosphere, temperature $180^{\circ} \mathrm{C}$ and $100 \%$ relative humidity for 10-12 hours.

5. The finished product of blocks, panels or slabs is commonly shrink-wrapped in plastic and transported directly to the construction site.

\section{Material balance for 10 tons per day factory capacity}

Find below in figure 1, the flow diagram and material balance for 10 ton production capacity of thermostone [8].

\begin{tabular}{|c|c|c|c|c|c|c|c|c|c|}
\hline \multicolumn{10}{|l|}{ Raw materials: } \\
\hline & $\begin{array}{l}\text { Proportion } \\
\text { wt\% }\end{array}$ & \multicolumn{3}{|r|}{$\begin{array}{l}\text { Water vapor } \\
\text { due to primary }\end{array}$} & & & & & \\
\hline Sand & $25.00 \%$ & \multirow{4}{*}{$\begin{array}{l}\text { Mixerto } \\
\text { Slurry }\end{array}$} & & drying & \multicolumn{2}{|c|}{ For 10 hours min. } & \multicolumn{2}{|c|}{ Product (kg): } & 10008 \\
\hline Lime $(\mathrm{CaO})$ & $7.00 \%$ & & & & & & & & \\
\hline Portland Cement & $26.00 \%$ & & \multirow{2}{*}{ do } & \multirow[t]{2}{*}{ e } & \multirow{2}{*}{\multicolumn{2}{|c|}{$\begin{array}{c}\text { Autoclave at } 180^{\circ} \mathrm{C}, 10 \mathrm{~atm} \\
\text { for curing, } 10-12 \text { hours }\end{array}$}} & & & \\
\hline Aluminum Powder & $0.04 \%$ & & & & & & & & \\
\hline Water & $40.00 \%$ & \multirow{2}{*}{\multicolumn{3}{|c|}{$\begin{array}{l}\text { Poured to Greased Mould for } \\
\text { about } 4 \text { hours, reactions }\end{array}$}} & $\uparrow$ & & & & \\
\hline Clay (remaining) & $1.96 \%$ & & & & & $\downarrow$ & \multirow{3}{*}{\multicolumn{2}{|c|}{$\begin{array}{c}\text { Product LWC } \\
\text { (lightweight } \\
\text { concrete) }\end{array}$}} & \\
\hline & & \multirow{2}{*}{\multicolumn{3}{|c|}{$\begin{array}{l}\text { accours to evolved million } \\
\text { hydrogen gas bubbles which }\end{array}$}} & \multirow{4}{*}{$\begin{array}{l}\text { High } \\
\text { pressure } \\
\text { steam }\end{array}$} & Water (kg) & & & \\
\hline Input raw material (kg): & 13700 & & & & & 96 & & & \\
\hline Sand (kg) & 3425 & \multirow{2}{*}{\multicolumn{2}{|c|}{$\begin{array}{l}40-45^{\circ} \mathrm{C} \text { that expand } \\
\text { origional volume to twice. }\end{array}$}} & & & & \multirow{3}{*}{$\begin{array}{l}\text { Density } \\
\text { of block } \\
\mathrm{gm} / \mathrm{cc}:\end{array}$} & \multirow{3}{*}{0.5} & \\
\hline $\mathrm{CaO}(\mathrm{kg})$ & 959 & & & & & & & & \\
\hline Cement (kg) & 3562 & & & & & & & & \\
\hline Alumina (kg) & 5.48 & & & & & & $\mathrm{~kg} / \mathrm{m}^{3}$ & 500 & \\
\hline Water $(\mathrm{kg})$ & 5480 & & & & & & & & \\
\hline Clay (kg) & 268.52 & & & & & & & & \\
\hline
\end{tabular}

Figure 1: $\quad$ Flow diagram and material balance for 10 ton thermostone blocks factory capacity.

\section{Primary feasibility study for 10 ton daily production}

1. Equipment cost:

Table 2 illustrates the cost of the equipment, taking into consideration that transportation trucks, forklifts and shovels could be used for multi positive income jobs. Working time in 10 ton capacity factory is actual 25\% max. We consider transportation cost effect in calculation equal to $25 \%$ of actual market cost. 
Table 2: The cost of equipment used in 10 ton thermostone capacity factory.

\begin{tabular}{|c|c|c|c|}
\hline Name of equipment & Number & $\begin{array}{c}\text { Cost of unit } \\
1000 \$\end{array}$ & $\begin{array}{c}\text { Total cost } \\
1000 \$\end{array}$ \\
\hline Jaw crusher 10 ton/day & 1 & 100 & 100 \\
\hline Grinder 10 ton/day & 1 & 100 & 100 \\
\hline Mixer & 1 & 100 & 100 \\
\hline Mould & 5000 & 0.05 & 250 \\
\hline Curing pallet & 500 & 0.05 & 25 \\
\hline Autoclave $10 \mathrm{~atm} 180^{\circ} \mathrm{C}$ & 1 & 300 & 300 \\
\hline Plastic Storage pallet & 500 & 0.05 & 25 \\
\hline Boiler & 2 & 250 & 500 \\
\hline Belts & 100 meter & 0.1 & 10 \\
\hline Forklifts & 2 & 100 & 200 \\
\hline Shavel & 1 & 200 & 200 \\
\hline Trucks & 2 & 200 & 400 \\
\hline \multicolumn{3}{|c|}{ Total equipment cost (thousands dollars) } & 2210 \\
\hline
\end{tabular}

2. The summary of annual feasibility study is shown in table 3 including investment cost, production cost, total revenue, annual profit and period of fixed investment payback.

Table 3: $\quad$ Summary of 10 ton capacity factory feasibility study.

\begin{tabular}{|l|l|}
\hline \multicolumn{2}{|c|}{ Summary of primary yearly economical study. All amounts in thousands \$ } \\
\hline Fixed investment cost & 4404 \\
\hline Production cost & 1356 \\
\hline Total revenue & 1699 \\
\hline Annual profit & 343 \\
\hline Fixed investment payback period & Two years and five months \\
\hline
\end{tabular}




\section{Conclusion}

1. The establishment of a thermostone factory in Koya city is a feasible project.

2. The soil analysis of Koay Heibat Sultan shows that it contains ferric, magnesium and alumina oxide which are important for high quality thermostone.

3. The production process is batch and takes approximately one day for a cycle including charging raw material and discharge products about.

4. The primary feasibility calculation for 10 tons capacity factory shows positive results. The annual profit $\$ 343,000$ for $\$ 4,404,000$ fixed investment cost with 2.4 year payback period.

\section{References}

[1] Wittmann, F. H. (ed.), Advances in Autoclaved Aerated Concrete, Proceedings 3rd RILEM, International Symposium on Autoclaved Aerated Concrete, ETH Zurich, p. 364 A.A. Balkema, Rotterdam (1992).

[2] Kurdistan Board of Investment 2006, http://www.kurdistaninvestment.org 2006/08/01 to 2013/09/08.

[3] Dunn, R. H. (1971). Precast low density concrete units. Lightweight Concrete. Publications p. 29. Detroit: American Concrete Institute.

[4] Ali A. Hussian Abdulameer, assistant professor - Najaf Technical Institute "Type of Failure in Cellular Concrete Blocks (Thermostone), Kufa Journal of Engineering Vol. 3, No 2 pp. 101-114 (2012).

[5] www.imiweb.org. The sole guide for masonry design and construction. International Masonry Institute, technology brief article; February (2010).

[6] Stefan Schnitzler, Applied Research Paper “Autoclaved Aerated Concrete as a Green Building Material” Applied Research on Sustainability and the Built Environment, UC Davis Extension October 2006

[7] Qusay Jar-Allah Hachim, Assist. Prof. Dr. Nada M. Fawzi; “The Effect of Different Types of Aggregate and Additives on the Properties of SelfCompacting Lightweight Concrete”. Journal of Engineering - Vol. 18, No. 8, August 2012.

[8] Roza Muhsin Fathi Shaweas, Safa Mustafa Shakir Mahmood, Fakhri H. Ibraheem; Student final year project, Chemical Engineering Department Koya University, 2012-2013, KRG-Iraq. 